\title{
A SPECIES OF MEGACHILE FROM BERMUDA ${ }^{1}$.
}

\section{By THEODORE B. MitCheLL}

A single female Megachile, captured during May, 1913, by Mr. Austin Brues in Bermuda, and sent to me by Dr. Bequaert for identification, proves to be either a variety of M. pruina Sm. or a very closely related species. Hence I will describe it here as a new variety of that species. If the male becomes available at some future time, it is possible that this will be shown to be specifically distinct from pruina.

\section{Megachile pruina bermudensis n.var.}

Size: Length $13 \mathrm{~mm}$; breadth of abdomen $5 \mathrm{~mm}$.; anterior wing $9 \mathrm{~mm}$.

Structure: Head broad; eyes slightly converging below; clypeus entire apically, the margin slightly thickened and shining medially; mandibles 4-dentate; cheeks as broad as eyes; vertex flat, hind margin slightly concave; lateral ocelli slightly nearer edge of vertex than to nearest eye; basal joint of flagellum longer than the second joint; hind metatarsi almost as long and as broad as the tibiæ; abdomen cordate, the apical margins of the segments rather strongly depressed laterally, but not medially; segment six straight in profile, slightly concave at sides in dorsal aspect, with only suberect black hairs visible in profile, the ventral plate bare except for a marginal fringe of black hairs, the apical margin extending as a bare lip beyond the apical fringe.

Puncturation: Close on cheeks and pleura, and on clypeus except in center; on the vertex close on either side of the median line, more sparse laterally; distinctly separ-

1Contribution from the Department of Zoology and Entomology, North Carolina State College, and published with the approval of the Director of the North Carolina Experiment Station as Paper No. 31 of the Journal Series. 
ated on mesonotum medially, but close laterally and anteriorly, and quite widely separated on scutellum; fine and close on basal abdominal segment, becoming relatively coarse and sparse on segment five, close and fine on segment six.

Color: Black; the tegulæ and antennæ below more fuscous; the wings quite uniformly infuscated, with fuscous nervures; spurs pale yellow.

Pubescence: White at sides of face, between antennæ, on cheeks, pleura, propodeum, coxæ, femora, tibiæ, and basal abdominal segment; black on vertex, mesonotum, scutellum, and discs of abdominal segments 2-5, with intermixed black hairs between antennæ; more fuscous on clypeus, front tibiæ and tarsi anteriorly, and on outer face of mid tarsi; segments 2-5 with narrow entire white apical fasciæ; segment six whitish tomentose, with erect black hairs laterally, these subappressed medially; scopa white, black on segment six and at extreme sides of segment five.

Type: Female; Bermuda. Coll. Austin Brues. (Museum of Comparative Zoölogy, Cambridge, Mass.).

This differs from typical pruina, as occuring in Florida, in the more lightly infuscated wings, and in the fact that the scopa of segment five is largely white. In M. pruina s. str. the scopa of segment five is entirely black, and that on segment four is black at the extreme sides. Otherwise, they are nearly identical. $M$. pruina was also described by Cresson as $M$. pinguis. The male was described by Robertson as $M$. floridana, and by myself as $M$. shermani. 

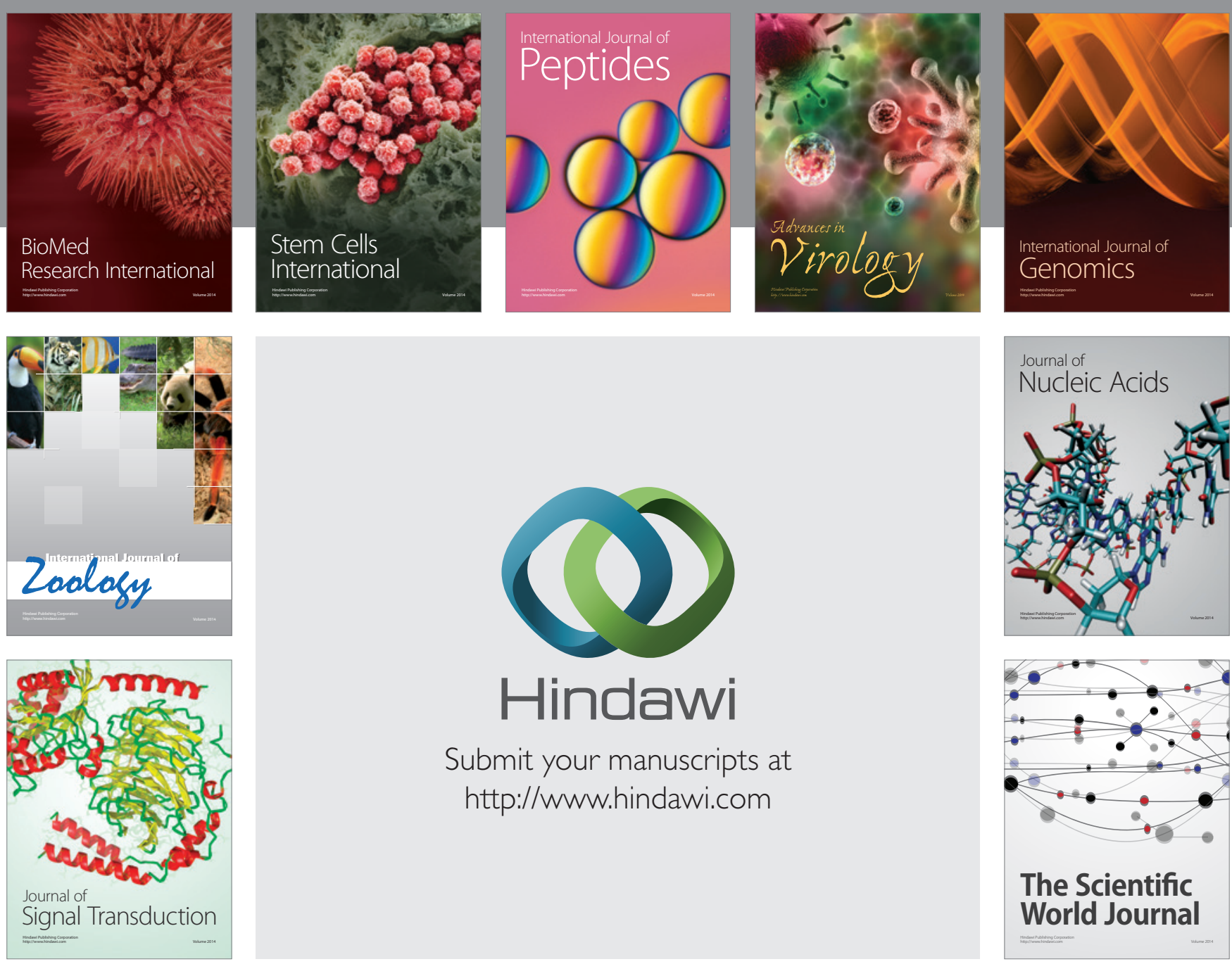

Submit your manuscripts at

http://www.hindawi.com
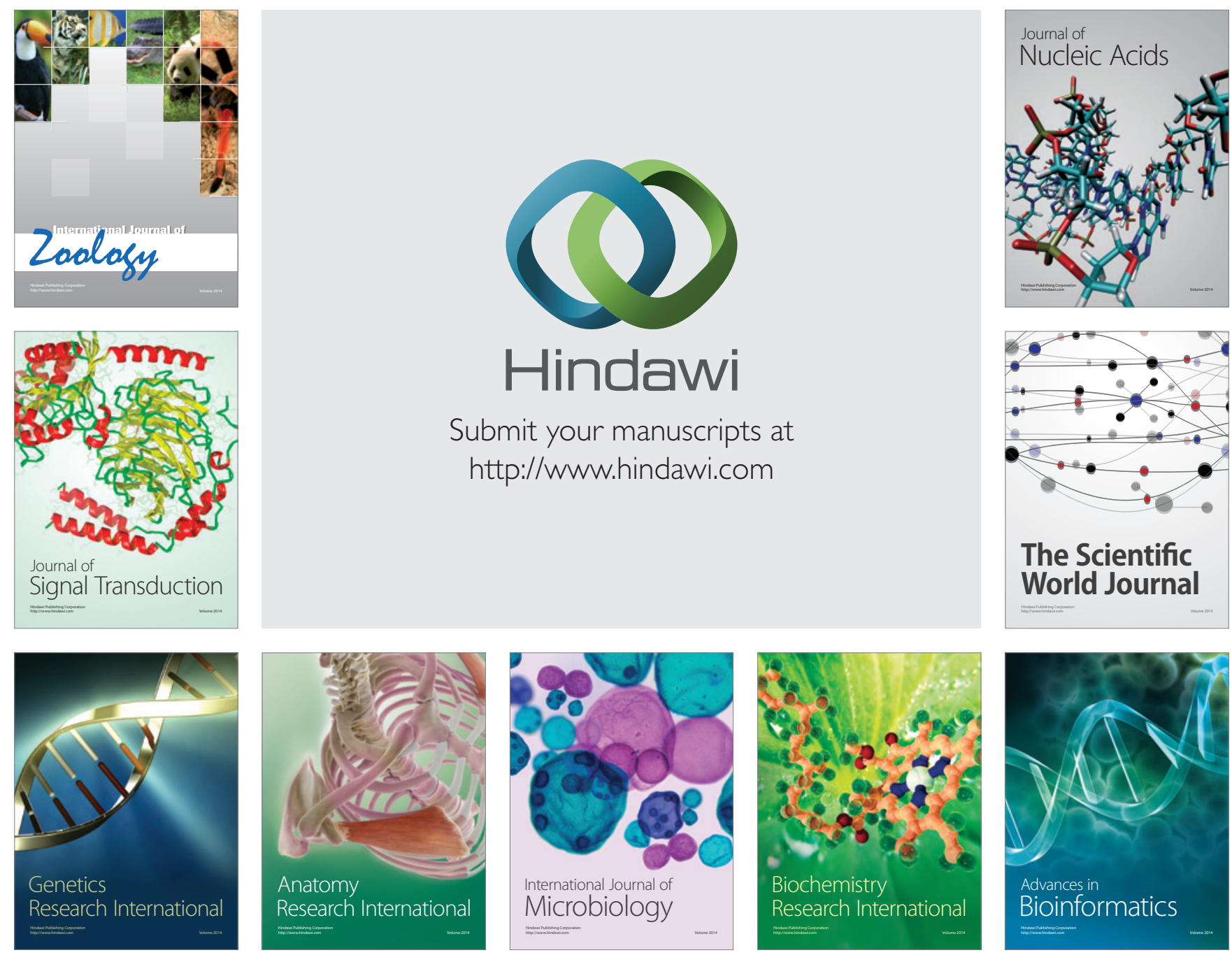

The Scientific World Journal
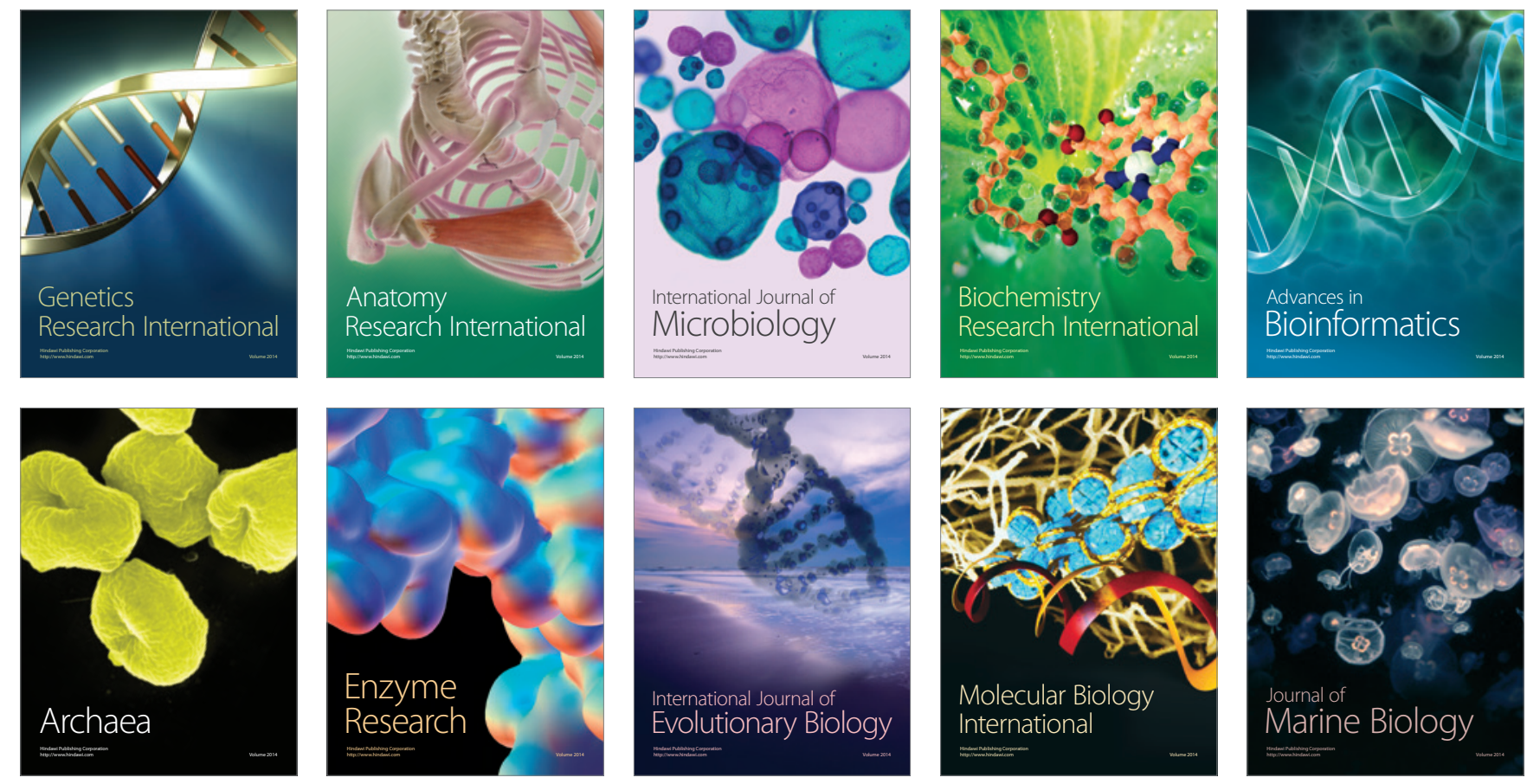